\title{
Application of Markov Chain Model and ArcGIS in Land Use Projection of Ala River Catchment, Akure, Nigeria
}

\author{
P. A. Adegbola, J. R. Adewumi*, O. A. Obiora-Okeke \\ Department of Civil Engineering, Federal University of Technology, Akure, Nigeria.
}

ABSTRACT: Increase land use change is one of the consequences of rapid population growth of cities in developing countries with its negative consequences on the environment. This study generates previous and present land use of Ala watershed and project the future land use using Markov chain model and ArcGIS software (version 10.2.1). Landsat 7, Enhanced Thematic mapper plus (ETM+) image and Landsat 8 operational land imager (OLI) with path 190 and row 2 used to generate land use (LU) and land cover (LC) images for the years 2000, 2010 and 2019. Six LU/LC classes were considered as follows: developed area (DA), open soil (OS), grass surface (GS), light forest (LF), wetland (WL) and hard rock (HR). Markov chain analysis was used in predicting LU/LC types in the watershed for the years 2029 and 2039. The veracity of the model was tested with Nash Sutcliffe Efficiency index (NSE) and Percent Bias methods. The model results show that the study area is growing rapidly particularly in the recent time. This urban expansion results in significant decrease of WL coverage areas and the significant increase of DA. This implies reduction in the available land for dry season farming and incessant flood occurrence.

KEYWORDS: Land cover, land use change, Markov chain, ArcGIS, watershed, urbanization

\section{INTRODUCTION}

Human migrations from rural to urban areas for comfortable living is an age long practice that is still in existence. The process of this migration leads to the occurrence of increased physical growth in the urban areas which eventually leads to urbanization. Urbanization affects the hydrological cycle which threatens the residents of the areas with the increasing risk of flooding. In general terms, land use change (LU) is the alteration of natural land formation. According to Adewumi et al. (2016), LU is one of the most significant factors for planning and management of issues relating to the use of land surface as well as studying of the complex relationships between human activities and global change. Bello et al. (2018) defined LU change as any physical, biological or chemical change resulting from poor land management.

Monitoring of environmental conditions and projects impact assessment of converting wetlands, forests, cultivated areas and water bodies to valuable infrastructure and for facilities installations through study of land use/land cover (LULC) dynamics and its pattern of change have gained popularity in recent time (Voogt and Oke 2003; Mukhopadhyay et al., 2014). Recently, research in global change has gained recognition as one of the most active research areas. It has been long established that human activities contributes extensively to rapid changes in the environment in an unprecedented manner while LULC has been recognized to be the most dynamic issue related to human and natural processes affecting global environmental change (Sathees et al., 2014). According to Roy et al. (2015), LULC changes due to human activities are responsible for the observed, increase in irreversible negative impact on global environmental systems.

Rimal et al. (2017) posited that urbanization, population growth and humanly induced deforestation for construction of roads, rails, water supply, building etc. are good indicators of economic growth. However, such development has its negative influence on land, soil, water and air.

The study of LU/LC change is a very important study for urban planners/decision makers to know parameters that are responsible for environmental changes for possible actions (Tendaupenyu et al., 2017; Li et al., 2017; Yi et al., 2016; Tiwari and Saxena, 2011). Nath et al. (2020) itemized changes that have been researched on to include landscape changes, landscape fragmentation, alterations in ecosystems, climate changes, urbanization, sustainable development, environment and risk evaluation. In all these researches, several techniques have been adopted by various researchers to predict LU/LC. Few of such techniques are: cellular automata (CA) - Markov chain model (Nath et al., 2020; Prayinto et al., 2020; Wu et al.,2019; Singh et al., 2018; Bello et al., 2018; Rimal et al., 2017), remote sensing and GIS datasets (Aitkenhead and Aalders, 2011; Pôças et al., 2011; Aitkenhead and Aalders, 2009; Weng, 2002), artificial neural network (ANN) and Markov chain (Rimal et al., 2020; Varga et al.,2019; Islam et al., 2018), GIS and remote sensing (Singh \& Singh , 2020; Viana et al.,2019; Dogiya et al., 2019; Hossen et al., 2019; 
Thakur et al. 2019). Hence, the importance of assessing, monitoring and modelling the past, present and future LULC conditions using modern simulation and analytical tools cannot be overemphasized in view of the recurrence of natural disasters across the globe (Rimal et al., 2017).

Geographic Information System (GIS) and Remote Sensing (RS) are very useful techniques that are globally recognised and accepted in the study of change analysis, spatiotemporal patterns of urbanization and simulation of LULC. When combined with other analytical tools, they have capacity to critically analyze any changes in earth surface and support decision making within the shortest possible time with high degree of accuracy (Rimal et al. 2020).

Combination of GIS with Markov model are popular tools in modelling LULC in urban and rural areas. It uses the initial occupation and transition probabilities of different states to determine the pattern of land alterations and forecast the future growth. High accuracy of the results obtained from these tools with observed data have been reported by many researchers (Sathees et al., 2014; Zhang et al., 2011; Dadhich \& Hanaoka 2010; Guan et al., 2008).

The study area is Akure, the State capital of Ondo State, Southwest, Nigeria. The town has been experiencing massive influx of people over the past decades. The recent inclusion of Ondo State as oil producing State in Nigeria has further increased migration rate into the town. High population growth, urbanization and industrialization in the peri-urban area of Ala river catchment has significantly affected changes in land use pattern. Ala River transverses the city of Akure and over $85 \%$ of Akure landed area drains into this River which often overrun its banks every year at the peak of raining season. Therefore, the objective of this study is to generate past and present land use of Ala catchment to project the future land use and land cover in response to increasing anthropogenic activities using Markov chain model and GIS.

\section{A. Study Area}

\section{MATERIALS AND METHODS}

Akure, capital of Ondo State is located between latitude 70 $12^{\prime} \mathrm{N}-7016$ ' $\mathrm{N}$ and longitude 50 9' $\mathrm{E}-5015^{\prime} \mathrm{E}$ as shown in Figure 1. Ala River is Akure drainage river located between latitude $7015^{\prime} \mathrm{E}$ - $7017^{\prime} \mathrm{E}$ and longitude $5010^{\prime} \mathrm{E}-5013^{\prime} \mathrm{E}$ in the Northern part of Akure urban township where the river channel runs from West - East. The total catchment area of Ala River was estimated to be $40 \mathrm{~km} 2$ or 40 million square meters in 2002 (Adewumi, 2003). Eke et al. (2017) reported that from a period spanning between 1986 and 2002, Akure town has expanded by 3852.70 ha which represents an increase in coverage area of more than 88.82\%. According to 1963 National Population Census figure, Akure had a population of 71,106 . However, with the creation of Ondo State in 1976, the population increased to 239,124 and 360,268 in 1991 and 2006 respectively as a result of high influx of people to the town in search of greener pasture. (Owoeye and Ibitoye, 2015; Federal Office of Statistics, 1992).

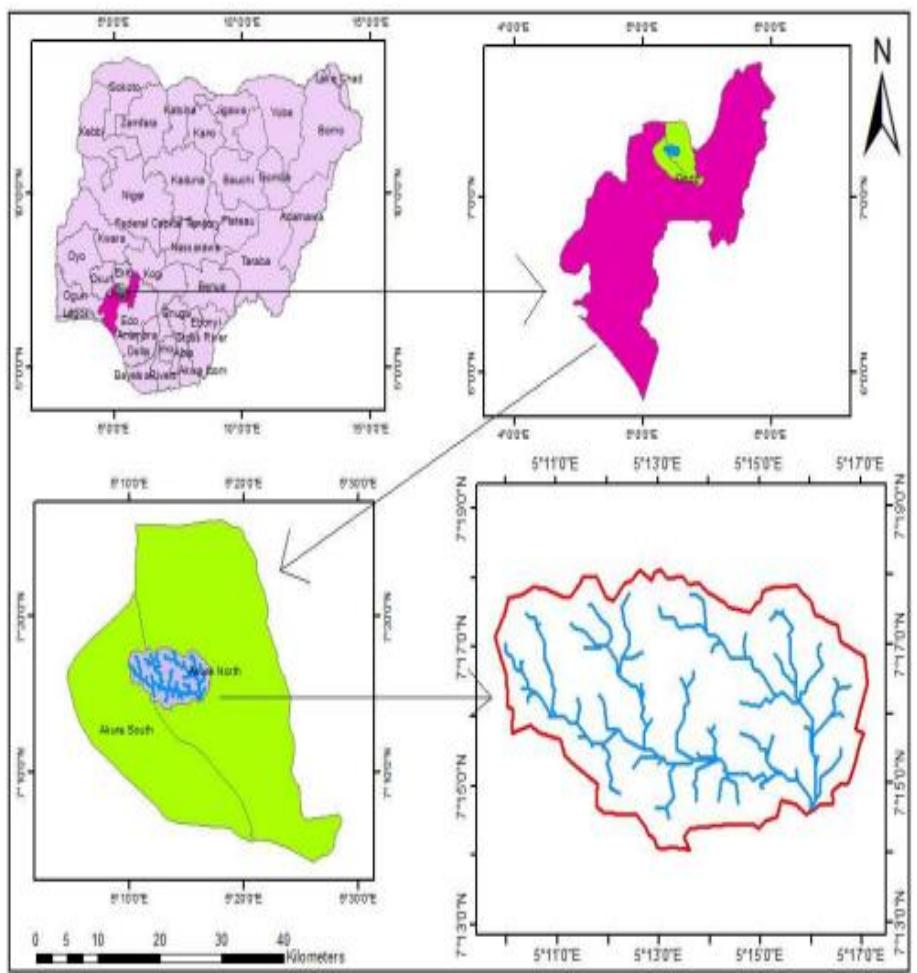

Figure 1: Map of Akure metropolis.

\section{B. Collection of Data}

The land degradation of Ala watershed was investigated by remote sensing and GIS to determine the extent of degradation. The multi dated images were compared to find out the nature of changes and amount that happened over time. The six scenarios considered were developed areas, open soil, grass surface, light forest, wetland and rock.

For effective study of changes in Land use (LU) and Land cover (LC) of Ala watershed, Landsat 7 Enhanced Thematic Mapper plus (ETM+) image and Landsat 8 Operational land Imager (OLI) obtained from the United States Geological Survey (USGS) website were used. The land use images were generated for the years 2000, 2010 and 2019 with path 190 and row 55. The Administrative map of Nigeria is the source from which the study area shape file was clipped out, this was done using Aeronautical Reconnaissance Coverage Geographic Information System (ArcGIS). All the images were enhanced, georeferenced and classified for the assessment of spatialtemporal pattern of land use and land cover changes in the area. Supervised classification method was used to classified satellite images.

LU/LC classification system was employed to classify the six distinct classes in the images (Coskun et al., 2008; Lillesand and Kiefer, 2003). The classified six land scenarios for years 2000, 2010 and 2019 were produced from Landsat images.

Using supervised classification procedure, information of interest (i.e., type of land cover) were identified from the satellite images. Thereafter, a statistical characterization of the reflectance for each land cover was developed with the help of image processing software system. After statistical classification, the image was classified for each information 
class by examining the reflectance for each pixel and decision was taken based on the signature it resembles mostly. Land use and land cover map was developed using maximum likelihood classifier (ref). This method is a statistical decision criterion employed to assist in the classification of overlapping signatures where pixels were assigned to the class of highest probability. This method of classification provides more precise information when compared to other classifiers but it is slower due to additional computations.

\section{Markov model in LU/LC change}

Before assessing the impact of urbanization, urbanization growth must first be determined. To attain this, the previous and the present land use need to be generated to forecast the future land use. To effectively do this, Markov chain model was used. Markov model is a useful technique for prediction of future LU/LC change when dynamics landscapes changes are difficult to project. The Markov process predicts future state of a system based on the preceding state by developing a transition probability matrix of LU/LC change starting from time one to time two. It shows the nature of changes as well as form the basis of future development forecasting (Logsdon et al., 1996). Markov method of predicting future state of a landscape requires the state transition of a system to another. This transition of one state to another state is described by the transition probability expressed below as:

$$
P=P_{\mathrm{ij}}=\left|\begin{array}{cccc}
P_{11} & P_{12} & \ldots . & P_{1 \mathrm{n}} \\
P_{21} & P_{22} & \ldots . & P_{2 \mathrm{n}} \\
P_{31} & P_{32} & \ldots . & P_{3 \mathrm{n}} \\
P_{41} & P_{42} & \ldots . & P_{4 \mathrm{n}}
\end{array}\right|
$$

where $P$ means probability from one state to another state (in this case state i to j) (Jianping et al., 2005; Guan et al., 2008; Sathees et al., 2014). Eq. (1) must meet the following two conditions:

$$
\begin{gathered}
\sum_{j=i}^{n} P_{i j}=1 \\
0 \leq P_{i j} \leq 1
\end{gathered}
$$

Obtaining a primary matrix and transition probability matrix $\left(P_{i j}\right)$ is a major step in Markov model. Hence, the Markov forecast model is expressed as stated in Eq. (4).

$$
P_{n}=P_{(n-1)} P_{i j}=P_{(0)} P_{i j}^{n}
$$

where $P_{n}$ represent the state probability while $P_{(0)}$ represents primary matrix (Jianping et al. 2005; Guan et al., 2008; Sathees et al., 2014).

\section{Validation/Testing the Model}

The veracity of the Markov chain model was validated using the observed land use values for 2019. The land use data observed for 2010 was used to project for 2019 and the projected 2019 results were compared with the observed 2019 land use data. These were compared and checked for similarities or differences using Nash Sutecliffe efficiency index $\left(\mathrm{E}_{\mathrm{f}}\right)$ and \% BIAS. The Nash Sutelcliffe efficiency index NSE method is widely used and it is calculated using Eq. (5) (Nash and Sutcliffe, 1970).

$$
\mathrm{NSE}=1-\left\{\frac{\sum_{i=1}^{n}\left(Y_{i}^{\text {obs }}-Y_{i}^{\text {sim }}\right)^{2}}{\sum_{i=1}^{n}\left(Y_{i}^{\text {obs }}-Y_{i}^{\text {mean }}\right)^{2}}\right\}
$$

where $Y_{i}^{o b s}$ is the $i^{\text {th }}$ observation for the component being assessed

$Y_{i}^{\text {sim }}$ is the $i^{\text {th }}$ simulated value for the component being assessed

$Y_{i}^{\text {mean }}$ is the mean of the observed data for the component being assessed,

$n$ is the total number of observations

Nash and Sutcliffe index results should fall within 1 to $\infty$. By interpretation, 1 is for a perfect fit while a value below 0 indicates that the average of the observed time series has a better predictor than the developed model (Krause et al., 2005).

This measures the average tendency of the simulated values to be larger or smaller than their values. The PBIAS between simulated and observed is given in percentage (\%) and represented in Eq. (6).

$$
\text { PBIAS }=100 \times\left\{\frac{\text { Sum }(\text { simulated }- \text { observed })}{\text { Sum }(\text { observed })}\right\}
$$

\section{RESULTS AND DISCUSSION}

\section{A. Land Use and Topography of Ala Watershed}

The six scenarios considered were developed areas, open soil, grass surface, light forest, wetland and rock as shown in Figure 2. Ala watershed is not a plain ground and Figures 3 and 4 are contour and digital elevation maps of the Ala watershed showing the topography of the whole basin (with different elevations) and the tributaries flowing into Ala River. The maps show the direction of flow and the lowest point of the basin where the river exits at the South-East of the basin. The total area of the Ala watershed as extracted from the ArcGIS is $44.62 \mathrm{~km}^{2}$.

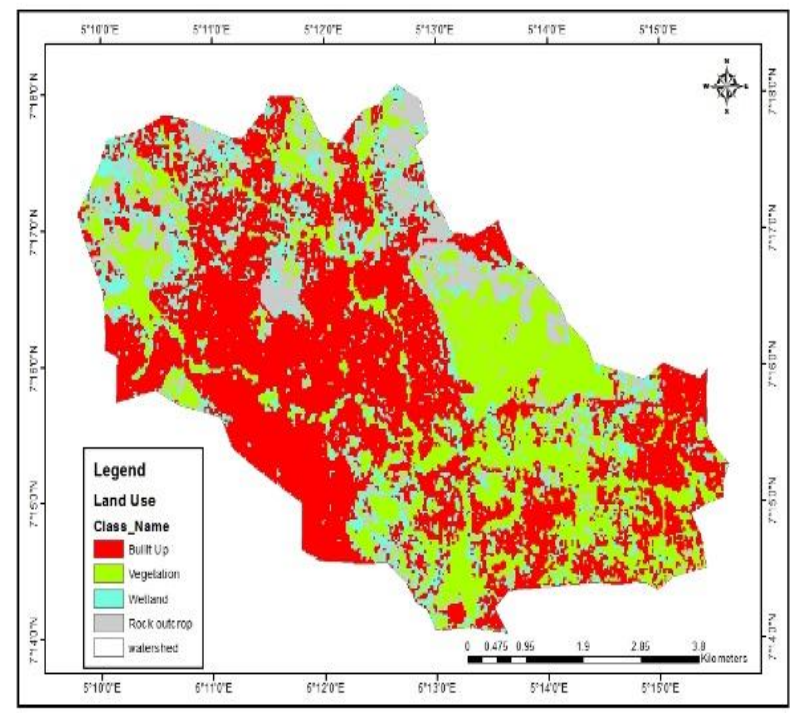

Figure 2: Land use/Land cover of the study area. 


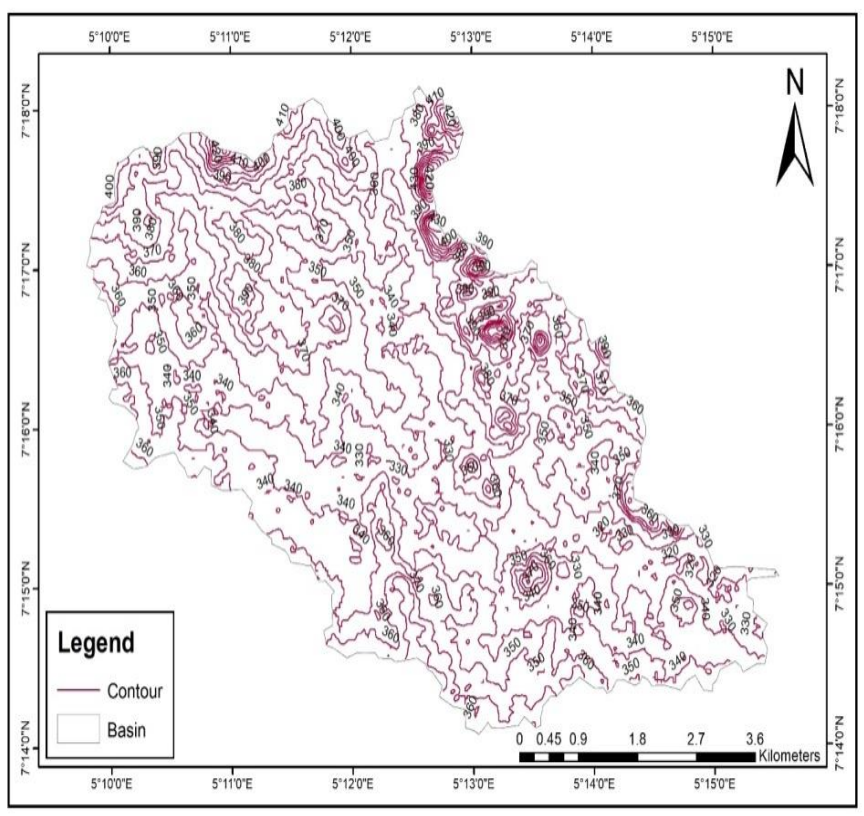

Figure 3: Contours map of the study area.

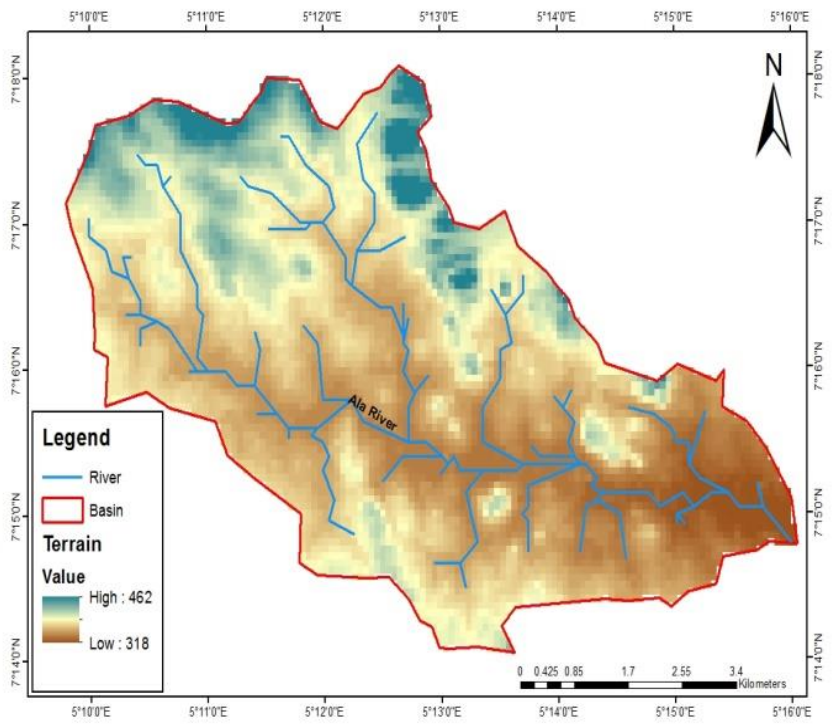

Figure 4: Elevation map of the study area.

\section{B. Primary Matrix for Ala River Watershed}

The primary matrix is based on the calculated areas of the land use types extracted from the Landsat images. The area statistics calculated for years 2000, 2010 and 2019 are listed in Table 1. Figures 5, 6 and 7 show the distribution of the land use class for these years and Figure 8 reveals the graphical representation of the land use class for easy interpretation. Worthy of note in Figure 8 is the progressive nature of the built-up areas and the declining nature of the wetland. This connotes that the built-ups take place at the wetland from years
2000 to 2019 . The primary matrix becomes $P_{(o)}=[22.66,0.32$, $5.15,0.38,10.42,5.67]$ for further analysis with transition probability matrices in generation of future LU/LC.

Table 1: Area Statistics for the years 2000, 2010 and 2019.

\begin{tabular}{lccc}
\hline LU/LC Classes & $\mathbf{2 0 0 0}$ & $\begin{array}{c}\text { Area }\left(\mathbf{k m}^{2}\right) \\
\mathbf{2 0 1 0}\end{array}$ & $\mathbf{2 0 1 9}$ \\
\hline Developed area & 8.93 & 12.62 & 22.66 \\
Open soil & 2.00 & 1.29 & 0.32 \\
Grass surface & 4.82 & 5.97 & 5.15 \\
Light forest & 0.43 & 1.57 & 0.38 \\
Wetland & 24.86 & 22.72 & 10.42 \\
Hard rock & 3.55 & 0.52 & 5.67 \\
\hline
\end{tabular}

It is obvious that the whole watershed is dominated by developed area which comprises of residential and commercial services. This may be attributed to the increase in population growth amongst other factors stated earlier that get people attracted to the city center. In the space of 19 years, the developed areas have increased from $8.93 \mathrm{~km}^{2}$ to $22.66 \mathrm{~km}^{2}$ land coverage. This rate of increase of built-up areas within a short space of time implies reduction in percolation and flood storage capacity of the catchment thus recent increase in flood events and extent. This is alarming, hence the need for this study. Increase in built-up areas means loss of forest cover and wetland.

Conversely, from Figure 2, it is noticed that wetland areas recorded a significant drop in the area of coverage. For instance, between years 2000 and 2019, a reduction from 24.86 $\%$ to $10.42 \%$ was observed in wetland areas. This depicts that most of the developed areas experienced, occurred in wetland areas. Physical observation shows that the majority of the developments coming up in this watershed are on the water ways and swampy areas. The effect of this is flooding in the study area (Ibitoye et al., 2019; Olalekan and Fadesola, 2017; Ogunbodede et al., 2014; Fadairo, 2013; Oyinloye et al., 2013; Eludoyin et al., 2007). Noticeable also is the inconsistent values of the rock outcrop. This is due to human activities as at the time the satellite picks the image. For instance, rock formations are being removed by blasting from time to time during construction activities.

\section{Matrix of Transition Probability for Ala Watershed}

The transition probability is defined as the rate of transition from one state to another state within a specified period of time. It is calculated from the annual average rate of transition of a certain land use and land cover type. Table 2 shows transition matrix for six land use types trending from 2000 to 2019. Using Eq. (2), that is, the transition probability of land use type in 2019 converted into land use type in 2029 and 2039 was calculated. Tables 3 and 4 show the primary transition probability matrix of six types of land use during years 20192029 and $2019-2039$. 


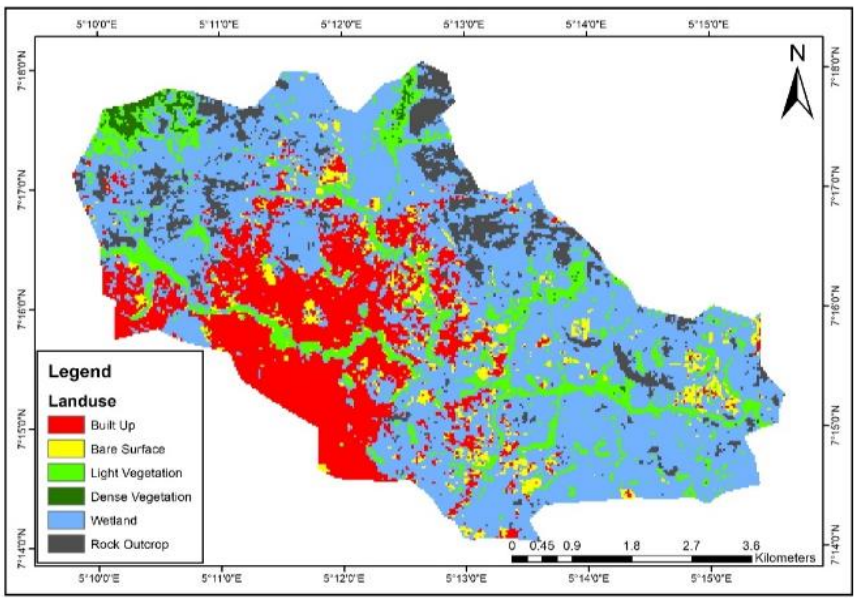

Figure 5: Land use map for 2000.

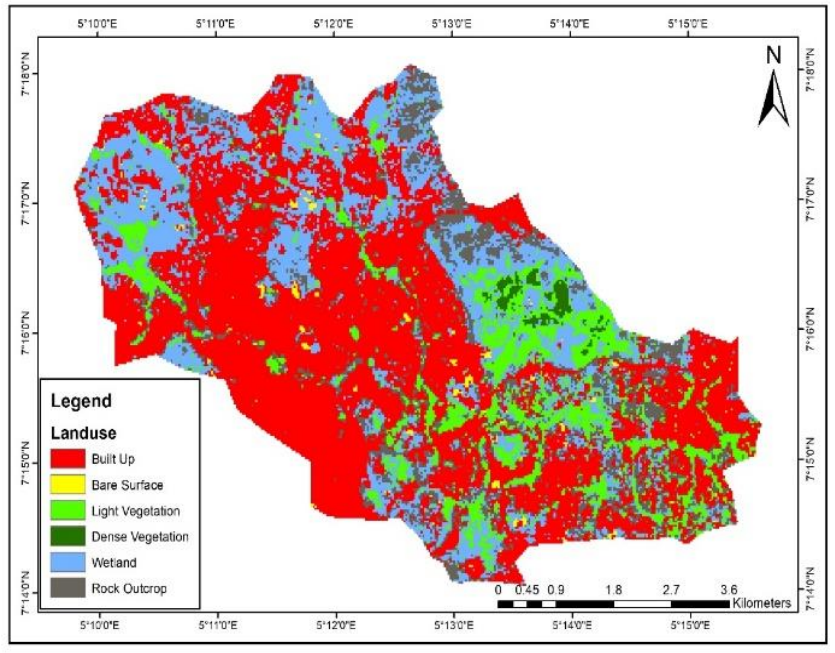

Figure 6: Land use map for 2010.

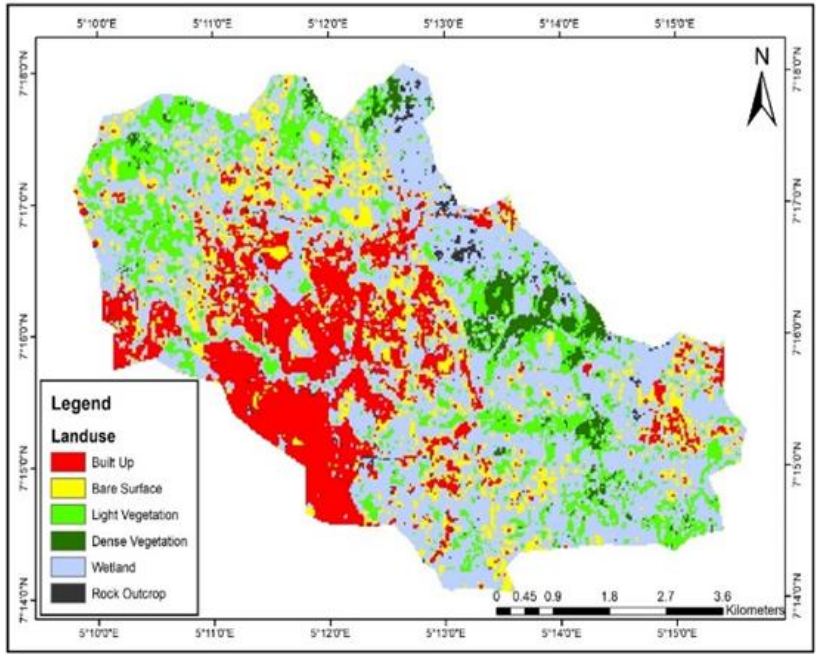

Figure 7: Land use map for 2019.

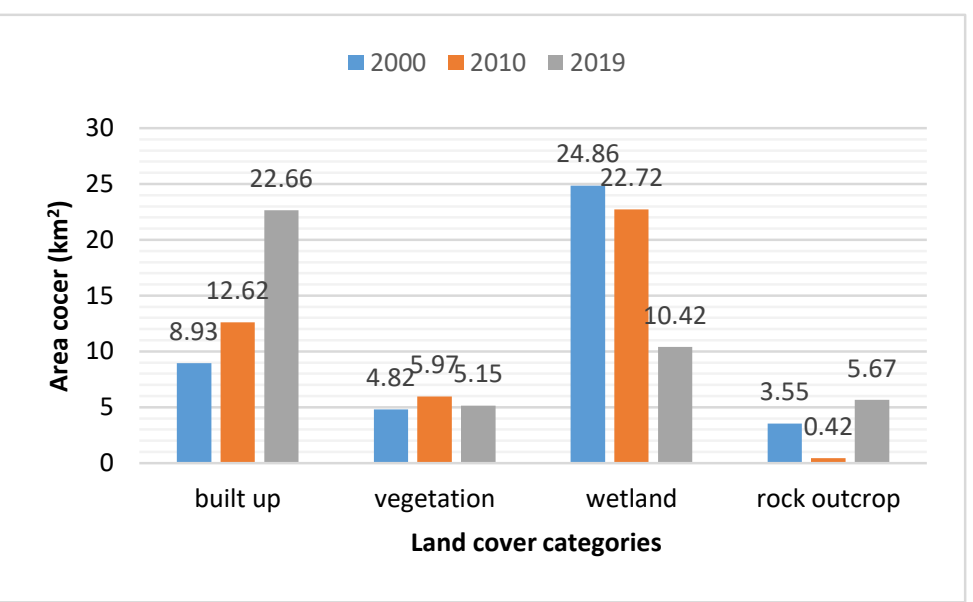

Figure 8: Square area of the land cover categories for 3 years.

Table 2: Transition matrix 2010-2019.

\begin{tabular}{|c|c|c|c|c|c|c|}
\hline 2010 & $\begin{array}{l}\text { Developed } \\
\text { area }\end{array}$ & $\begin{array}{c}\text { Bare } \\
\text { Surface }\end{array}$ & $\begin{array}{c}2019 \\
\text { Grass surface }\end{array}$ & $\begin{array}{l}\text { Light } \\
\text { forest }\end{array}$ & Wetland & $\begin{array}{l}\text { Hard } \\
\text { rock }\end{array}$ \\
\hline Developed area & 0.9423 & 0.0121 & 0.0000 & 0.0000 & 0.0000 & 0.0456 \\
\hline Open soil & 0.3006 & 0.4219 & 0.0838 & 0.0000 & 0.0294 & 0.1642 \\
\hline Light Veg. & 0.0126 & 0.0265 & 0.5456 & 0.2481 & 0.0601 & 0.1070 \\
\hline Dense veg & 0.0000 & 0.0000 & 0.2625 & 0.7064 & 0.0029 & 0.0283 \\
\hline Wetland & 0.1458 & 0.0475 & 0.3883 & 0.0000 & 0.1102 & 0.3081 \\
\hline Rock outcrop & 0.0325 & 0.0191 & 0.1679 & 0.0000 & 0.1659 & 0.6146 \\
\hline
\end{tabular}

Table 3: Transition matrix 2019-2029.

\begin{tabular}{ccccccc}
\hline $\mathbf{2 0 1 9}$ & $\begin{array}{c}\text { Developed } \\
\text { area }\end{array}$ & $\begin{array}{c}\text { Bare } \\
\text { surface }\end{array}$ & $\begin{array}{c}\mathbf{2 0 2 9} \\
\text { Grass surface }\end{array}$ & $\begin{array}{c}\text { Light } \\
\text { forest }\end{array}$ & $\begin{array}{c}\text { Wetland } \\
\text { rock }\end{array}$ & $\begin{array}{c}\text { Hard } \\
\text { Developed area }\end{array}$ \\
Open soil & 0.9571 & 0.0063 & 0.0000 & 0.0000 & 0.0240 & 0.0126 \\
Light Veg. & 0.5689 & 0.1535 & 0.0000 & 0.0000 & 0.1957 & 0.0819 \\
Dense veg & 0.0574 & 0.0054 & 0.4714 & 0.1179 & 0.2882 & 0.0597 \\
Wetland & 0.0124 & 0.0008 & 0.4629 & 0.3908 & 0.1183 & 0.0148 \\
Rock outcrop & 0.2410 & 0.0065 & 0.1751 & 0.0051 & 0.4274 & 0.1449 \\
\hline
\end{tabular}


Table 4: Transition matrix 2019-2039.

\begin{tabular}{lcccccc}
\hline \multicolumn{1}{c}{$\mathbf{2 0 1 9}$} & $\begin{array}{c}\text { Developed } \\
\text { area }\end{array}$ & $\begin{array}{c}\text { Bare } \\
\text { surface }\end{array}$ & $\begin{array}{c}\mathbf{2 0 3 9} \\
\text { Grass surface }\end{array}$ & $\begin{array}{c}\text { Light } \\
\text { forest }\end{array}$ & Wetland & $\begin{array}{c}\text { Hard } \\
\text { Rock }\end{array}$ \\
\hline Developed area & 0.9260 & 0.0077 & 0.0001 & 0.0000 & 0.0445 & 0.0217 \\
Open soil & 0.6959 & 0.0265 & 0.0300 & 0.0000 & 0.1730 & 0.0746 \\
Light Veg. & 0.1626 & 0.0059 & 0.3236 & 0.1012 & 0.3124 & 0.0943 \\
Dense Veg. & 0.0726 & 0.0040 & 0.4153 & 0.2003 & 0.2482 & 0.0597 \\
Wetland & 0.3617 & 0.0067 & 0.1626 & 0.0250 & 0.3218 & 0.1222 \\
Rock outcrop & 0.2390 & 0.0056 & 0.1239 & 0.0033 & 0.4396 & 0.1885 \\
\hline
\end{tabular}

Based on the transition matrix shown in Table 3, the probability of grass surface area is $47 \%$ for the period of 10 years. The probability of conversion from grass surface to light forest and wetland areas are about $12 \%$ and $29 \%$ respectively. Also, the probability of open soil changed to developed area and wetland areas is $57 \%$ and $20 \%$ respectively while the probability of wetland to change to developed area areas is 24 $\%$. It is noticeable in Table 4 that open soil is vulnerable to encroachment in the year 2039 having the transition probability matrix of $3 \%$.

The prediction of future $\mathrm{Lu} / \mathrm{Lc}$ in 2029 and 2039 was analyzed using Markov chain analysis. Figures 9 and 10 are projected digitized LU and LC maps of Ala watershed for future scenarios. Presented in Table 6 is the result of the past and projected Land use/Land cover. The result was converted into percentage as presented in Table 7. All the results gotten from the classified images shown in Table 7 were summarized in Figure 11 for easy interpretation. It is important to recognize from Table 6 that the observed and the predicted columns for 2019 were used to validate the model. The predicted 2019 was calculated from the observed data of 2010 and compared with the 2019 observed data. Having validated the model with Nash Sutcliffe efficiency index, the observed data was then used to forecast for 2029 and 2039.

Table 5: Area Statistics of Past and Predicted LU/LC.

\begin{tabular}{ccccccc}
\hline & & \multicolumn{3}{c}{ Area $\left(\mathbf{k m}^{2}\right)$} & Predicted & \\
Land use Type & $\mathbf{2 0 0 0}$ & $\mathbf{2 0 1 0}$ & $\mathbf{2 0 1 9}^{*}$ & $\mathbf{2 0 1 9 * *}$ & $\mathbf{2 0 2 9}$ & $\mathbf{2 0 3 9}$ \\
\hline Developed area & 8.93 & 12.62 & 22.66 & 17.61 & 30.02 & 34.53 \\
Open soil & 2.00 & 1.29 & 0.32 & 1.68 & 0.04 & 0.02 \\
Grass surface & 4.82 & 5.97 & 5.15 & 1.37 & 5.12 & 4.97 \\
Light forest & 0.43 & 1.57 & 0.38 & 2.68 & 0.37 & 0.37 \\
Wetland & 24.86 & 22.72 & 10.42 & 2.68 & 3.41 & 0.91 \\
Rock outcrop & 3.55 & 0.42 & 5.67 & 11.07 & 5.60 & 3.79 \\
\hline
\end{tabular}

*Values obtained from satellite **Value predicted by the model. The two values were used to validate the model before predicting for 2029 and 2039 using Eq.(4).

Table 6: Percentage representation of Past and Predicted LU/LC.

\begin{tabular}{ccccccc}
\hline & & & & Area (\%) & & \\
Land use Type & & $\mathbf{2 0 0 0}$ & $\mathbf{2 0 1 0}$ & $\mathbf{2 0 1 9}$ & $\mathbf{2 0 2 9}$ & $\mathbf{2 0 3 9}$ \\
\hline Developed area & 20 & 28 & 51 & 67 & 77 \\
Open soil & 4 & 3 & 1 & 12 & 11 & 2 \\
Grass surface & 11 & 13 & 1 & 1 & 1 \\
Light forest & 1 & 4 & 23 & 8 & 2 \\
Wetland & 56 & 51 & 13 & 13 & 8 \\
Rock outcrop & 8 & 1 & & & \\
\hline
\end{tabular}




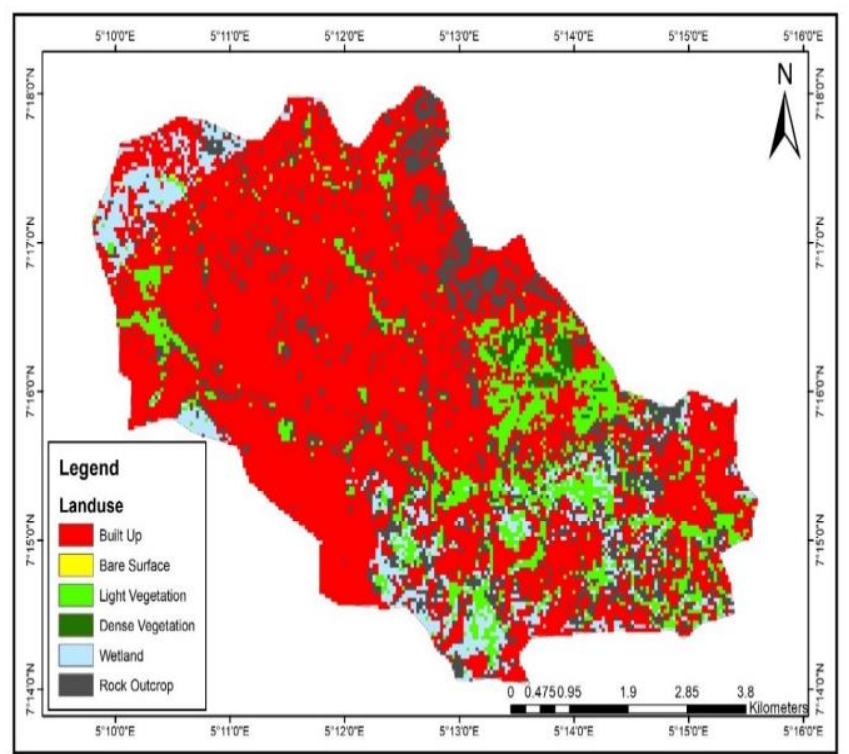

Figure 9: Projected Land use/Land cover for 2029.

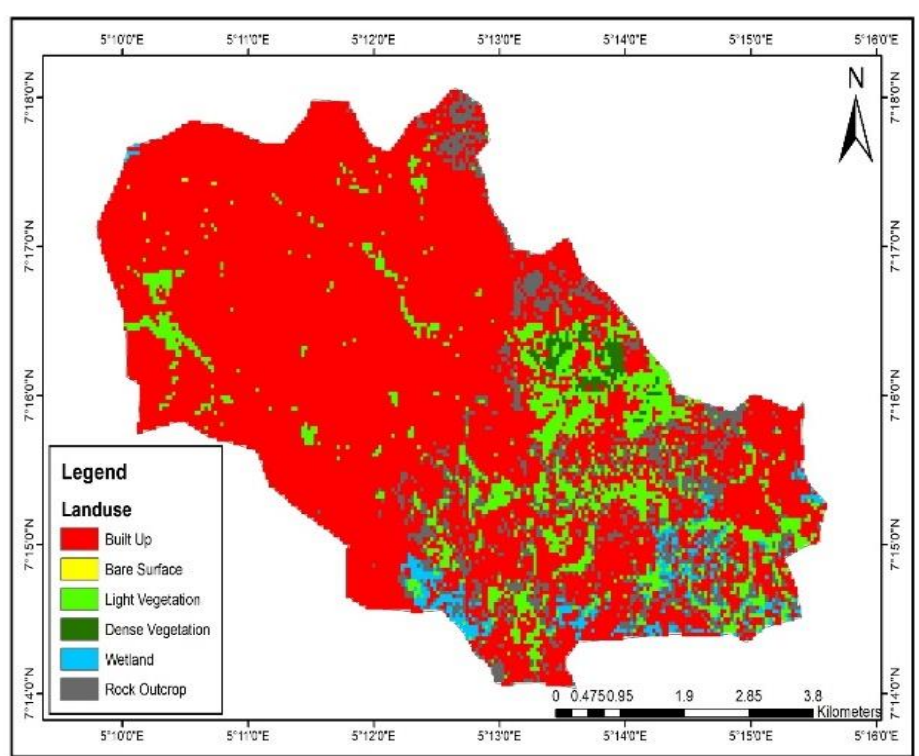

Figure 10: Projected Land use/Land cover for 2039.

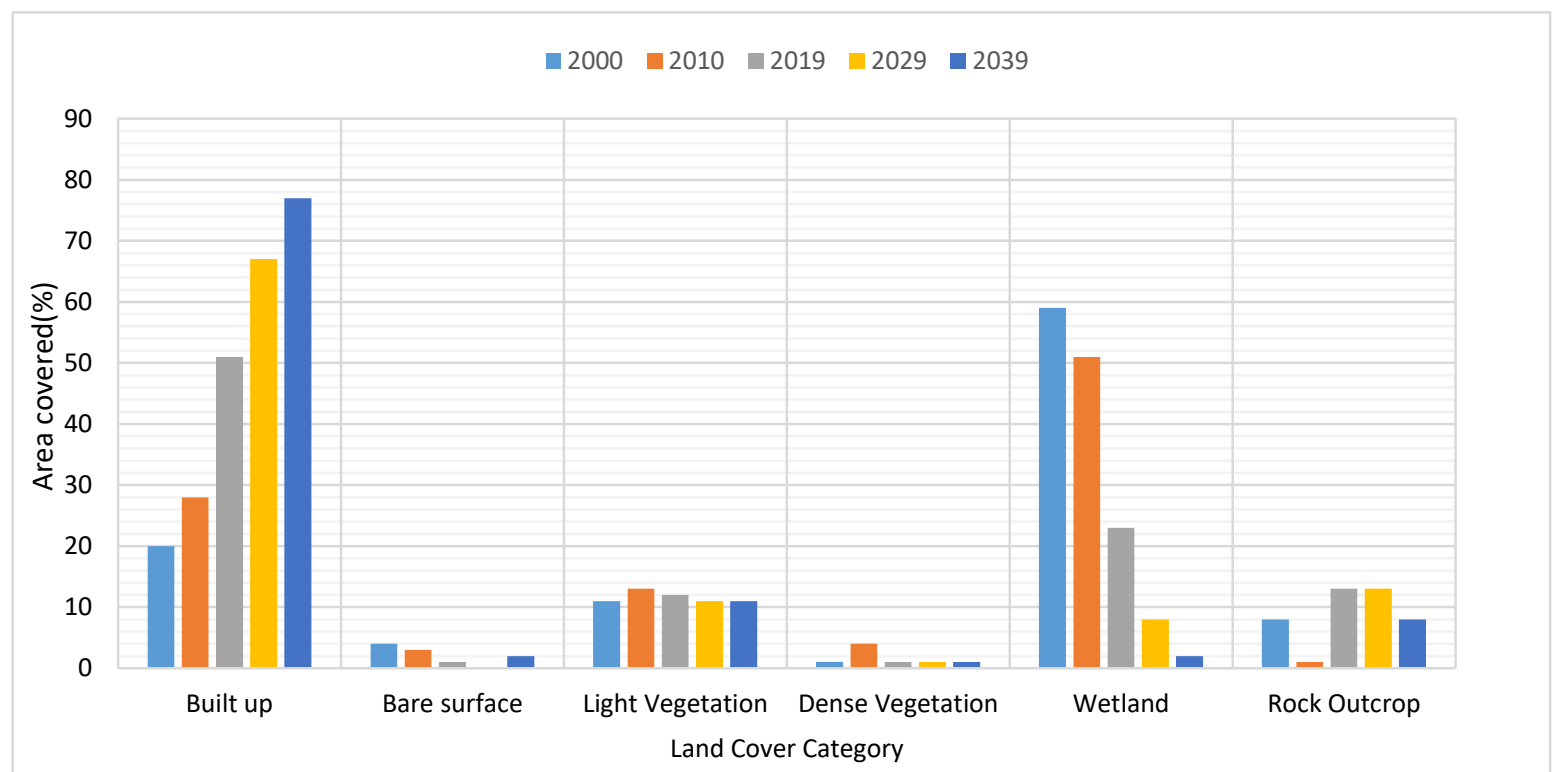

Figure 11: Area covered in percentage of the Past and Predicted LU/LC of the Ala watershed.

\section{CONCLUSION}

This study has established that, Akure township (35.6\% of which is drained by the watershed) is fast increasing in urbanization and land use development. This is obvious in the results of the analysis that indicated the developed area will increase from $20 \%$ land coverage in the year 2000 to $77 \%$ by the year 2039 if the urbanization followed the present trend. Conversely, the wetland areas will reduce from $56 \%$ coverage in 2000 to $2 \%$ by 2039 . This indicates that the natural equilibrium of Ala watershed is endangered by the urbanization pressure. Results of this study are in accordance with Dadhich and Hanaoka (2010), Islam and Ahmed (2011), Mukhopadhyay et al.
(2014), Sathees et al. (2014) and Zhang et al. (2011) in terms of using Markov Chain Model to predict land cover changes. These findings indicate that it is feasible to simulate LU/LC change using remote sensing and Markov chain model. However, it is important to mention that the transition probability in the Markov chain model was assumed to be uniform hence; it was difficult to accommodate influence of random variables such as climate change, change in population, government policy or human disturbance.

\section{ACKNOWLEDGEMENT}

The authors appreciate the Management of the Federal University of Technology, Akure for support. 


\section{REFERENCES}

Adewumi, J.R.; J. K Akomolafe; F.O Ajibade.; and B.B. Fabeku. (2016). Application of GIS and Remote Sensing Technique to Change Detection in Land use/Land cover Mapping of Igbokoda, Ondo State, Nigeria. Journal of Applied Science and Process Engineering, 3(1), 34 - 54

Aitkenhead, M.J. and I. H. Aalders. (2009). Predicting land cover using GIS, Bayesian and evolutionary algorithm methods. Journal of Environmental Management, 90(1), 236-250.

Aitkenhead, M. J. and I. H. Aalders. (2011). Automating land cover mapping of Scotland using expert system and knowledge integration methods. Remote Sensing of Environment, 115(5), 1285-1295.

Bello, H. O.; O. I. Ojo and A. S. Gbadegesin. (2018). Land Use/land cover change analysis using Markov-Based model for Eleyele Reservoir. Journal of Applied Sciences and Environmental Management, 22(12), 1917-1924

Coskun, G. H.; U. Alganci; and G. Usata. (2008). Analysis of land use change and urbanization in the Kucukcekmece water basin (Instabul, Turkey) with temporal satellite data using remote sensing and GIS. Sensors 8, 7213-7223.

Dadhich, P. N.; S. Hanaoka. (2010). Remote sensing, GIS and Markov's method for land use change detection and prediction of Jaipur district. Journal of Geomatics. 4, 9-15.

Dodiya, D.; S. Goswami.; D. Chauhan; M. Bhuva.; and R. Parekh. (2019). Land use \& land cover change detection using GIS \& remote sensing. Change, 6(04).

Eludoyin.; A. O., M. O. Akinbode; and E. Okuku. (2007). Combating Flood Crisis with Geographical Information System: An Example from Akure Southwestern Nigeria. In International Symposium on New Direction in Urban Water Management UNESCO, Paris (pp. 12-14)

Fadairo, G. (2013). An Empirical Evidence to the Urban Storm Water Crisis and the Way out in Akure, Nigeria. European Int J Sci Technol, 2, 53-66.

Federal Office of Statistics. (1992). Federal Government Printer, Lagos, Nigeria. Federal Republic of Nigeria Official Gazette.

Guan, D.; W. Gao.; K. Watari.; and H. Fukahori. (2008). Land use change of Kitakyushu based on landscape ecology and Markov model. Journal of Geographical Sciences, 18(4), 455-468.

Hossen, S.; M. K. Hossain.; and M. F. Uddin. (2019). Land cover and land use change detection by using remote sensing and GIS in Himchari National Park (HNP), Cox's Bazar. Bangladesh. Journal of Science, Technology and Environment Informatics, 7(02), 544-554.

Ibitoye, M. O.; A. A. Komolafe; A. A. S. Adegboyega.; A. O. Adebola.; and O. D. Oladeji. (2019). Analysis of vulnerable urban properties within river Ala floodplain in Akure, Southwestern Nigeria. Spatial Information Research, 115.

Islam, K.; M. F. Rahman.; and M. Jashimuddin. (2018). Modeling land use change using cellular automata and artificial neural network: the case of Chunati Wildlife Sanctuary, Bangladesh. Ecological Indicators, 88, 439-453Islam, M. S.; and R. Ahmed. (2011). Land use change prediction in Dhaka city using GIS aided Markov chain modeling. Journal of Life Earth Science, 6, 81-89.
Jianping, L.; Z. Bai.; and G. Feng. (2005). RS-and-GISsupported forecast of grassland degradation in southwest Songnen plain by Markov model. Geo-spatial Information Science 8:104-06.

Krause, P.; F. Base.; and D. P. Boyle. (2005). Comparison of different efficiency criteria for hydrological model assessment. Advances in Geoscience, 5, 89-97.

Li Z.; X. Li.; Y. Wang.; A. Ma.; and J. Wang. (2004). Land-use Change Analysis in Yulin Prefecture, Northwestern China using Remote Sensing and GIS. Lanzhou: A paper published in Cold and Arid Regions Environmental and Engineering Research Institute, Chinese Academy of Science, Lanzhou, 730000 China.

Lilles, T.M.; and R.W. Kiefer. (2003). Remote sensing and image interpretation (4th Edition). Wiley, New York: John Wiley \& Sons Inc.

Logsdon, M. G.; J. E Bell.; V. F. Westerlund. (1996). Probability mapping of land use change: a GIS interface for visualizing transition probability. Comput Environ Urban Syst. 20, 389-398

Mukhopadhyay, A.; A. Mondal.; S. Mukherjee.; D. Khatua.; S. Ghosh.; D. Mitra.; and T. Ghosh. (2014). Forest cover change prediction using hybrid methodology of geoinformatics and Markov chain model: A case study on subHimalayan town Gangtok, India. Journal of Earth System Science, 123(6), 1349-1360.

Nash, J.E.; and J.E. Sutcliffe. (1970). River flow forecasting through conceptual models. Part 1: A discussion of principles. Journal of Hydrology 10, 282-290

Nath, B.; Z. Wang.; Y. Ge.; K. P. Islam.; R. Singh.; \& Z. Niu. (2020). Land Use and Land Cover Change Modeling and Future Potential Landscape Risk Assessment Using Markov-CA Model and Analytical Hierarchy Process. ISPRS International Journal of Geo-Information, 9(2), 134

Ogunbodede, E. F.; and R. A. Sunmola. (2014). Flooding and traffic management in Akure (Nigeria) metropolitan environment. International Journal of Innovation and Scientific Research, 7(2), 121-130.

Olalekan, B. G.; and A. Fadesola. (2017). Review of Best Practice Approaches in Combatting Vulnerability to Flood Disaster Risk in Ala-River Flooding Akure, Ondo State, Nigeria. Journal of Environmental Studies, 3(1), 5.

Owoeye, J.O.; and O.A. Ibitoye. (2015). Analysis of Akure Urban Land Use Change Detection from Remote Imagery Perspective. Hindawi Publishing Corporation.

Oyinloye, M. A., O. I. Olamiju.; and B. S. Oyetayo. (2013). Combating flood crisis using GIS: Empirical evidences from ala river floodplain, Isikan Area, Akure, Ondo State, Nigeria. Communications in Information Science and Management Engineering, 3(9), 439.

Pôças, I.; M. Cunha.; and L. S. Pereira. (2011). Remote sensing-based indicators of changes in a mountain rural landscape of Northeast Portugal. Applied Geography, 31(3), 871-880.

Rimal, B.; S. Sloan.; H. Keshtkar.; R. Sharma.; S. Rijal.; and U. B. Shrestha. (2020). Patterns of Historical and Future Urban Expansion in Nepal. Remote Sensing, 12(4), 628. 
Rimal, B.; L. Zhang.; H. Keshtkar.; N. Wang.; and Y. Lin. (2017). Monitoring and modeling of spatiotemporal urban expansion and land-use/land-cover change using integrated Markov chain cellular automata model. ISPRS International Journal of Geo-Information, 6(9), 288.

Roy, S.; K. Farzana.; M. Papia.; and M. Hasan (2015). Monitoring and prediction of land use/land cover change using the integration of Markov chain model and cellular automation in the Southeastern Tertiary Hilly Area of Bangladesh. International Journal, Science and Basic Applied Research, 24(4), 125-148.

Sathees Kumar.; Nisha Radhakrishnan.; and Samson Mathew. (2014). Land use change modelling using a Markov model and remote sensing. Geomatics, Natural Hazards and Risk, 5(2), 145-156.

Singh, B.; and C. G. Singh (2020). Analysis of Land Use/Land Cover Change Detection Using Remote Sensing and GIS of Fatehgarh Nau Abad Village, Bathinda, Punjab. In Geoecology of Landscape Dynamics Springer, Singapore.

Singh, S. K.; S. Mustak.; P. K. Srivastava.; S. Szabó.; and T. Islam. (2015). Predicting spatial and decadal LULC changes through cellular automata Markov chain models using earth observation datasets and geo-information. Environmental Processes, 2(1), 61-78.

Tendaupenyu, P.; C. H. D. Magadza.; and A. Murwira. (2017). Changes in landuse/landcover patterns and human population growth in the Lake Chivero catchment, Zimbabwe. Geocarto International, 32(7), 797-811.

Thakur, S.; I. Mondal; P. B. Ghosh.; P. Das.; and T. K. De. (2019). A review of the application of multispectral remote sensing in the study of mangrove ecosystems with special emphasis on image processing techniques. Spatial Information Research, 1-13.
Tiwari, M. K.; and A. Saxena. (2011). Change detection of land use/landcover pattern in an around Mandideep and Obedullaganj area, using remote sensing and GIS. International Journal of Technology and Engineering System, 2(3), 398-402.

Varga, O. G.; R. G. Pontius Jr.; S. K. Singh.; and S. Szabó. (2019). Intensity Analysis and the Figure of Merit's components for assessment of a Cellular Automata-Markov simulation model. Ecological indicators, 101, 933-942

Viana, C. M.; and J. Rocha. (2018). Spatiotemporal analysis and scenario simulation of agricultural land use land cover using GIS and a Markov chain model. In Geospatial Technologies for All: Short Papers, Posters and Poster Abstracts of the 21th AGILE Conference on Geographic Information Science (pp. 12-15). Lund University: Lund, Sweden

Voogt, J.A.; and T. R. Oke. (2003). Thermal remote sensing of urban climates. Remote sensing Environ. 86, 370384.

Weng, Q. (2002). Land use change analysis in the Zhujiang Delta of China using satellite remote sensing, GIS and stochastic modelling. Journal of environmental management, 64(3), 273-284.

Wu, H.; Z. Li.; K. C. Clarke.; W. Shi.; L. Fang.; A. Lin and J. Zhou (2019). Examining the sensitivity of spatial scale in cellular automata Markov chain simulation of land use change. International Journal of Geographical Information Science, 33(5), 1040-1061

Yi, Y.; Y. Zhao.; G. Ding.; G. Gao.; M. Shi.; and Y. Cao. (2016). Effects of urbanization on landscape patterns in a mountainous area: a case study in the Mentougou district, Beijing, China. Sustainability, 8(11), 1190

Zhang, R.; C. Tang; S. Ma; H. Yuan; L. Gao and W. Fan. (2011). Using Markov chains to analyze changes in wetland trends in arid Yinchuan Plain, China. Mathematical and Computer Modelling, 54(3-4), 924-930. 